\title{
The New Institutionalism and Africa
}

\section{Citation}

Bates, Robert H., Steven A. Block, Ghada Fayad, and Anke Hoeffler. 2013. “The New

Institutionalism and Africa." Journal of African Economies 22 (4) (July 30): 499-522. doi:10.1093/ jae/ejs031.

\section{Published Version}

doi:10.1093/jae/ejs031

\section{Permanent link}

http://nrs.harvard.edu/urn-3:HUL.InstRepos:11595727

\section{Terms of Use}

This article was downloaded from Harvard University's DASH repository, and is made available under the terms and conditions applicable to Open Access Policy Articles, as set forth at http:// nrs.harvard.edu/urn-3:HUL.InstRepos:dash.current.terms-of-use\#OAP

\section{Share Your Story}

The Harvard community has made this article openly available.

Please share how this access benefits you. Submit a story.

Accessibility 


\title{
The New Institutionalism and Africa
}

\author{
Robert H. Bates \\ Department of Government \\ Harvard University \\ Steven A. Block, \\ The Fletcher School \\ Tufts University \\ Ghada Fayad \\ Oxford Center for the Analysis of Resource Rich Economies \\ Department of Economics \\ University of Oxford \\ Anke Hoeffler \\ Center for the Study of African Economies \\ University of Oxford
}

\begin{abstract}
After briefly reviewing the new institutionalism, this article uses the history of political reform in Africa to test its key tenet: that power, if properly organized, is a productive resource. It does so by exploring the relationship between changes in political institutions and changes in economic performance, both at the macro- and the microlevel. The evidence indicates that political reform (Granger) causes increases in GDP per capita in the African subset of global data. And, at the micro-level, it demonstrates that changes in national political institutions in Africa strongly relate to changes in total factor productivity in agriculture.
\end{abstract}




\section{Introduction}

This article proceeds in several stages. Section 2 provides an overview of the new institutionalism and reviews recent changes in the politics and economics of Africa. Sections 3 and 4 then makes use of the data supplied by Africa's efforts at political reform to address a core issue in the new institutionalism: the relationship between democracy and development. At both the macro- and the micro-level, we find, the evidence supports institutionalist arguments: variation in political institutions bears a systematic, significant and plausibly causal relationship to variation in economic performance.

\section{Background}

\section{A The Approach}

To introduce the new institutionalism, it is useful to juxtapose it against public choice theory - an approach which it has largely eclipsed. The contrast between the two schools highlights the new institutinalist's core argument: that political power can be socially productive.

As do others (Hirshleifer 1994), public choice theorists identify two routes to the accumulation of wealth. One is production and exchange in markets and the other the use of power in politics. In markets, they argue, no one needs consent to an exchange that renders him worse off. Insofar as the pursuit of wealth takes place within markets, then, it is compatible with the social welfare (Buchanan 1989). In political settings, by contrast, power can be marshaled to elicit involuntary transfers. This is true when political institutions underpin despots, of course; but, Buchanan and others argue (e.g. 
Page 3

Buchanan and Tullock 1962), it is also true in democracies, where political majorities can expropriate minorities and where concentrated minorities, for their part, can use public power to extract private benefits while distributing the costs widely. The public choice school thus views power as a threat to social welfare.

Contrast this argument with that of the new institutionalists (e.g. North and Thomas 1973; North 1981; North 1990). While conceding that indeed power can destroy wealth, they also insist that it can promote its creation. Highlighting the pervasiveness of market failure, they note that political sanctions can be structured so as to strengthen the forces of production. Tort law weakens incentives for non-performance, for example, making possible agreements that previously would have been shunned. And governments can enforce property rights in ways that align private interests with the social welfare in situations that might otherwise have led to opportunistic - and self-defeating — behavior. Whereas the public choice school emphasized the use of coercion to impose involuntary losses, the new institutionalists thus emphasize its use to facilitate social gains. They view political institutions as a form of capital that, if properly configured, can unleash the productive potential of the economy, making economic growth possible (Bates, Greif et al. 2002).

In search of evidence for such arguments, the new institutionalism has pursued several lines of inquiry. Of particular relevance to Africa is research into the relationship between democracy and development. 
Writing in 1959, Seymour Martin Lipset reported a strong and positive correlation between income per capita and democracy in a global cross section of nations (Lipset 1959). Economic development, he argued, leads to democracy. Lipset's work thus anticipated a major portion of the contemporary agenda in the new institutionalism. ${ }^{1}$

Lipset's finding invites a dynamic and causal interpretation. It was therefore startling that when estimating Markov transition models Przeworski et al. (2000) failed to find a significant relationship between the level of income per capita and the likelihood of a transition to democracy. While Boix and Stokes (2003) and Epstein, Bates et al. (2006) have challenged Przeworski et al.'s finding, it has subsequently been replicated by Acemoglu, Johnson et al. (2008). ${ }^{2}$

Beginning in the 1980s, political forces from within Africa and without engineered sweeping political changes, introducing democratic institutions into what had been authoritarian settings. Among their objectives was to secure institutional reform and to reignite growth in Africa's stagnant economies. Late-century Africa thus, in effect, offers an experiment that empowers us to evaluate institutionalist arguments.

\footnotetext{
${ }^{1}$ See the contributions to Helpman, E., Ed. (2008). Institutions and Economic Performance. Princeton NJ, Princeton University Press.

${ }^{2}$ The portions of this essay devoted to the Lipset hypothesis draw heavily from Fayad, G., et al. (2011). Income and Democracy: Lipset's Law Inverted. OxCarre Research Paper 61. Oxford, Oxford Center for the Analysis of Research Rich Economies. Those devoted to agriculture draw heavily draw from Bates, R. H. and S. Block (2010). Revisiting African Agriculture: Institutional Change and Productivity Growth. Cambridge MA, Weatherhead Center.
} 
Page 5

\section{B The Case of Africa}

As documented in academic studies (Ndulu, O'Connell et al. 2008) and official reports (World Bank 1991), those addressing Africa's poor economic performance in the postindependence period traced its roots to Africa's political systems. Overwhelmingly single party or military regimes, (see Figure 1), they were narrowly based, resting on a coalition composed of urban-based, public-sector employees, manufacturers, and industrial firms. As best summarized in (Ndulu, O'Connell et al. 2008), the economic policies of many of these regimes were characterized (inter alia) by:

- Tariff policies that protected domestic manufacturing (but not agriculture).

- Industrial regulations that conferred market power on the producers of manufactured goods but on the purchasers of agricultural products.

- Over-valuation of domestic currencies.

Given that manufacturing received tariff protection from imports, while agriculture did not, the last of these measures further tilted relative prices in favor of the urban sector.

Taken together, these policies shifted relative prices against agriculture - the largest single sector of most of Africa's economies. One result was slower growth, as incentives eroded for persons to invest capital or labor power in farming. ${ }^{3}$ Given that agricultural

\footnotetext{
${ }^{3}$ As reported in Ndulu, B. J., S. A. O'Connell, et al. (2008). The Political Economy of Economic Growth in Africa, 1960-2000. New York, Cambridge University Press, the adoption of these policies (which, taken together, they call "control regimes") imposed a loss of nearly two percentage points to the annual rate of growth.
} 
Page 6

exports generated a significant portion of Africa's earnings in foreign markets, another was external debt.

Although international donors pressured Africa's governments for policy reform, the governments were reluctant to comply. As authoritarian regimes, they were based on a narrow set of organized interests and the fortunes of each depended to a significant extent upon government policies. While Africa's farmers stood to benefit from policy reform, they lay widely scattered, resided in culturally distinctive communities, and therefore found it difficult to organize. As the logic of collective action (Olson 1985, Bates 1981, Becker 1983) would suggest, the urban coalition - highly concentrated spatially and economically -- therefore prevailed, and this mix of policies remained in place despite its economic costs.

Recognizing the political forces at play, those who sought to alter government policies and thereby secure the renewal of economic growth in Africa sought to alter Africa's political institutions. They sought thereby to alter political incentives so that politicians would no longer regard such policies as politically winning. In particular, they recognized that should Africa's rural dwellers once again be able to vote, then, given their numbers, their interests, and their presence in numerous electoral districts, they could render policies that damaged the fortunes of farming politically unsustainable. In pursuit of policy reform, Africa's creditors abroad therefore joined domestic reformers at home in demanding a return to open political competition and majority rule. 
As discussed by Dunning (2004), until the late 1980s, the Cold War initially kept external pressures in check. Following the breakup of the Soviet Union, however, foreign ministries in the West were less inclined to stay the hand of finance ministries, and the latter enjoyed far greater latitude in their negotiations with debtor governments. Financial institutions were now free openly to act in concert with domestic reformers. In the absence of political reform, they could - and did - suspend further lending. In pursuit of foreign capital, Africa's governments capitulated, conceding the right to form opposition parties that could compete for votes (see Figure 1). The change in institutions enfranchised Africa's rural population.

These changes were inherently valuable; for social scientists, moreover, they offered an opportunity to observe and to measure the relationship between political change and changes in economic performance. Focusing on the Lipset hypothesis, section 3 relates political reform in Africa to the growth of national incomes. Section 4 relates political change to changes in total factor productivity in agriculture. Both report evidence supportive of institutionalist arguments.

\section{Institutions and Development}

We begin with the work of Fayad, G., et al. (2011), who have conducted the most recent investigation of the Lipset hypothesis. Fayad et al. themselves target the work of Acemoglu, Johnson, et al. (2008) (henceforth AJRY), who had concluded that Lipset was wrong. Using a variety of estimators and including fixed effects, AJRY found that, pace Lipset, there was no relationship between GDP per capita and democracy in global samples, 1960-2000. Fayad, G., et al. (2011) concur with Grundlach and Paldam's 
Page 8

(2009) critique of AJRY, arguing that by applying estimators which assumes cross sectional parameter homogeneity while including annual and country fixed effects, AJRY purge from their panels useful information, thereby predisposing them to fail in their search for a relationship between income and democracy. Fayad G., et al. (2011) instead employ an augmented version of the Pooled Mean Group (PMG) estimator (Pesaran, Shin, and Smith 1999) which relaxes the assumption of cross-sectional parameter homogeneity. They thereby gain access to variation unavailable to AJRY, and in doing so detect a statistically significant relationship between institutions and economic performance that had eluded AJRY.

The PMG estimator allows intercepts, slope coefficients and error variances to differ across panel members. More specifically, it allows the short-run coefficients to vary across countries, while restricting long-run relationships to be homogeneous. ${ }^{4}$

The model they estimate is:

$$
\begin{aligned}
& \Delta d_{i t}=\varphi_{i}\left(d_{i, t-1}-\mu_{i}-\beta y_{i t}-\eta \bar{y}_{t}-\alpha \bar{d}_{t}\right) \\
& +\sum_{j=1}^{p-1} \lambda_{i j} \Delta d_{i, t-j}+\sum_{j=0}^{p-1} \delta_{i j} \Delta y_{i, t-j}+\sum_{j=0}^{p-1} v_{i j} \Delta \bar{d}_{i, t-j}+\sum_{j=0}^{p-1} \omega_{i j} \Delta \bar{y}_{i, t-j}+\varepsilon_{i t}
\end{aligned}
$$

Where ${ }^{d_{i t}}$ represents democracy and ${ }^{y_{i t}}$ represents income per capita for country $i$ at time $t$, and $\bar{y}_{t}=N^{-1} \sum_{i=1}^{N} y_{i t}, \bar{d}_{t}=N^{-1} \sum_{i=1}^{N} d_{i t}$ respectively represent their cross-sectional

\footnotetext{
${ }^{4}$ In the context of this research, the estimator in effect "assumes" that in the short run - or while adjusting to a common long-run equilibrium - each country's political institutions respond differently to income shocks.
} 
averages. Crucially, the error term ${ }^{\varepsilon_{i t}}$ is identically and independently distributed across $\mathrm{i}$ and $t$ even in the presence of common time effects. Country intercepts -- unobserved country heterogeneity - are captured by the term ${ }^{\mu_{i}}$.

The second part of equation (1) includes the lagged changes of income and democracy; the coefficients represent the short-run adjustment terms and are assumed to vary across countries. We do not report the short-run coefficients below. The first part of equation (1) captures the common long-run relationship between income and democracy. The slope coefficients -- $\beta, \eta$, and $\alpha$-- measure the long-run response of democracy to income, world income and world democracy. $\varphi$ is the error correction coefficient and indicates the speed of adjustment If the system is dynamically stable and converges to a long-run equilibrium, then this coefficient will be negative and less than one in absolute value. We report these long-run coefficients below.

Fayad G., et al. (2011) apply this model to a panel of 105 countries spanning the years 1960-2000. As did AJRY, Fayad G., et al. (2011) employ the Polity IV democracy index ${ }^{5}$ and the Penn World Tables' (PWT 6.3) chain weighted estimates of real GDP per capita income. When they estimate the relationship between democracy and income from pooled data using OLS, they - as did AJRY -- find the coefficient on the income variable to be positive and significant. And when they include time and country fixed effects, they - as did AJRY -- find that the coefficient does not significantly differ from

\footnotetext{
5 Which distributes over a range spanning the interval between perfect autocracies (score of -10) and perfect democracies (score of 10).
} 
Page 10

zero $^{6}$. But when Fayad, G., et al. (2011) employ the pooled mean group estimator, they find the coefficient significant and negative. Fayad, G., et al. (2011) confirm that differences in the samples do not account for differences in the estimates. Rather, they conclude, the difference arises from differences in their choice of estimator.

\section{A Principal Findings}

The major results derived from this model appear in the first column of Table 1, while estimates derived from the mean group estimator appear in the second. The Hausman test in column 3 result testifies to the validity of the long-run homogeneity restrictions imposed by the PMG estimator. ${ }^{7}$ The coefficients generated by the pooled mean estimator suggest that income is negatively and significantly related to democracy.

Given that the model is linear log, they suggest that a $10 \%$ increase in per capita income leads in the long run to a roughly 0.12 unit decrease in the polity scale.

Proceeding further, Fayad G., et al. (2011) disaggregate their sample. They then find significant regional differences in the relationship between income and democracy. They find that while running both ways in the global sample, in the Africa subsample, Granger causality runs from democrcy to income (Table 2) and that the relationship is

\footnotetext{
${ }^{6}$ Because it allows for heterogeneous intercepts, the PMG estimator can incorporate country-specific fixed effects. But because it estimates the model for each country separately, it can not allow the inclusion of year fixed effects. To correct for potential cross-section dependence in the estimated errors, Fayad G., et al. (2011) - as do Binder and Offermanns (2007) - therefore augment the model with the cross-sectional averages of the dependent variable and regressors.

${ }^{7}$ More precisely, the difference between both MG and PMG estimators is used to compute a Hausman-type statistic.
} 
significantly positive. As can be seen in Table 3, in Sub-Saharan Africa, a one unit increases in the Polity score is associated with a $1.5 \%$ increase in income per capita. ${ }^{8}$

Institutional change in Africa thus associates with changes in incomes. ${ }^{9}$ Political reform in Africa appears to have generated evidence that supports the arguments of both reformers and scholars alike and produced higher incomes for Africa's impoverished economies. $^{10}$

Recent political developments suggest that these gains are under threat, however. While "17 countries are leading the way" (Radelet, 2010), a sumber seem to be backsliding. Over the past decade, there have been seven successful coups and a further six failed attempts. Over the same period, according to the Ibrahim Index, in 15 countries, governance failed to improve ${ }^{11}$, while, according to The African President's Index , in 22, leadership was extremely poor. ${ }^{12}$ Political incumbents in Burkina Faso, Cameroon, Chad, Senegal and Uganda successfully altered their constitutions in order to allow them to compete yet again for the presidency (see Posner and Young, 2007); in each instance,

\footnotetext{
${ }^{8}$ The Hausman test in column 3 result testifies to the validity of the long-run homogeneity restrictions imposed by the PMG estimator.

${ }^{9}$ This conclusion finds additional support in the report by Radelet, S. (2010). Emerging Africa: How 17 Countries Are Leading the Way. Washington DC, Center for Global Development. See also Fosu, A. K. (2008). "Democracy and Growth: Implications of Increasing Electoral Competiveness." Economic Letters 100(September): 442-444.

${ }^{10}$ This conclusion finds additional support in the report by Radelet, S. (2010). Emerging Africa: How 17 Countries Are Leading the Way. Washington DC, Center for Global Development. See also Fosu, A. K. (2008). "Democracy and Growth: Implications of Increasing Electoral Competiveness." Economic Letters 100(September): 442-444 and Nkurunziza, J. D. and R. H. Bates (2003). Political Institutions and Economic Growth in Africa. CID Working Paper No. 98. Cambridge MA, Center for International Development, Harvard University.

${ }_{11}$ Own calculations based on the Ibrahim Index of Governance http://www.moibrahimfoundation.org/en/section/the-ibrahim-index (accessed 18 Dec. 2010)

12 The African Presidents Index: The good, the bad and the ugly. The East African. Nairobi._December 27, 2010 - January 2, 2011.
} 
Page 12

the incumbents won and remained in office. Clearly, institutional reform remains work in progress.

\section{Evidence from the Micro- Level}

The evidence thus far has come from the macro- level: It consists of relationships between political institutions and measures of the total economic product. But recall the argument advanced in the introduction, which appealed to the utility functions and policy preferences of politicians, to the structure of political competition, and, in particular, to changes in the composition of the electorate resulting from the enfranchisement of farmers. In the section that follows, we draw upon these finer features of the polity and upon micro-level data on the economy to explore once again the relationship between political institutions and economic performance.

\section{A Total Factor Productivity}

In a recent paper, Steven Block (2010) combined data from 44 countries over 46 years (1961-2007) to generate estimates of changes in total factor productivity in African agriculture. In the initial years of independence, he found, total factor productivity dramatically declined. In the early 1980s, however, it began to grow. And by the early 2000s, its average annual rate of growth was over four times faster than it had been 25 years earlier. His estimates suggest that the average rate of TFP growth in the baseline estimate is $0.97 \%$ per year, a figure that falls to $0.87 \%$ per year when we adjust for land quality and to $0.59 \%$ per year when we include adjustments for the quality of labor. For our purposes, however, the key finding is the post-independence decline and subsequent rise of cross-country agricultural productivity growth in Africa, which give rise to two 
Page 13

questions. Did changes in Africa's political institutions bear a systematic relationship to changes in the performance of Africa's rural economy? And, if so, through what mechanism did their impact run? We argue that they did, both directly and through their impact on government policies.

\section{A. The Data}

Using aggregate crop output figures for each country, and Africa-specific prices and PPP exchange rates, ${ }^{13}$ Block derives his estimates from a semi-parametric specification of a constant returns to scale Cobb-Douglass production function:

(1)

$$
y_{i}(t)=c+\sum_{j=\mathbf{2}}^{k} \beta_{j} x_{i j}(t)+\sum_{j=1}^{\mathbf{k}} \lambda_{j} z_{i j}(t)+\sum_{j=\mathbf{1}}^{m} \gamma_{j} p_{i j}(t)+g(T D(s))+\sum_{h=1}^{n-1} \varphi_{h} C D_{h}+\varepsilon_{i}(t)
$$

where $y_{i}(t)$ is aggregate crop output for country $i$ in year $t, x_{i j}(t)$ is a vector of $j$ conventional agricultural inputs (land, chemical fertilizer, tractors, and livestock); $z_{i j}(t)$ are quality shifters associated with these inputs (average years of schooling to adjust labor quality, as well as rainfall and irrigated land share to adjust for the quality of land); $p_{i j}(t)$ are other potential explanations for TFP growth (to include political competition); $T D$ are annual time dummies; and $C D$ are country dummies. All variables are in logs, normalized by the size of the labor force in agriculture.

\footnotetext{
13 Block (2010) constructs these aggregates from crop-specific output data published by the Food and Agricultural Organization of the UN. Other studies simply employ the FAO's pre-constructed output aggregates, which are based on global prices and exchange rates. Block's estimates thus more closely reflect the circumstances actually faced by Africa's farmers.
} 
To derive the country-specific rates of agricultural TFP growth, he estimates equation (1) country-by-country. The "baseline" estimates (shown in the cross-country aggregates in Figure 2) exclude the adjustments for input quality contained in the vector $z$. He then reestimates the function while adjusting for land quality (by controlling for the effect of annual rainfall and irrigated land share), and then re-estimates it once again while adjusting as well for labor quality (by controlling for average years of schooling). While the estimate of TFP growth is reduced by the extent to which those additional variables "explain" the initial baseline estimate, the adjustments help to differentiate between productivity increases resulting from the use of improved inputs from those that result from increases in the efficiency with which these inputs are employed.

We seek to relate these changes in total factor productivity to changes in political institutions. As a measure of institutions, we make use of a scale that provides a measure of the degree of political competition that the incumbent chief executive faced when coming to office. ${ }^{14}$ For each country in each year, the scale assigns a number that indicates whether:

1 -- No executive exists.

2 - An executive exists but was not elected.

3 - The executive was elected, but was the sole candidate.

4 - The executive was elected, with multiple candidates competing for the office.

5 -- Multiple parties were also able to contest the executive elections.

\footnotetext{
${ }^{14}$ The measure is taken from the World Bank's Data Base of Political Institutions: Beck, T., G. Clarke, et al. (2001). "New Tools and New Tests in Comparative Political Economy: The Database of Political Institutions." World Bank Economic Review. The measure was devised by the Africa Research Program at Harvard, who established that it yields a cumulative (Guttman) scale. See Bates, R. H., K. Ferree, et al. (1996). Toward the Systematic Study of Transitions. Development Discussion Paper No. 256. Cambridge MA, Harvard Institute for International Development.
} 
6 -- Candidates from more than one party competed in executive elections, and the winner won more than $75 \%$ of the votes.

7 -- Candidates from more than one party competed in executive elections, and the winner won less than $75 \%$ of the vote.

We employ as our measure a dummy variable, named "electoral competition," that takes the value 1 when a government is rated 6 or above and 0 otherwise.

When discussing public policy, we employ two measures. One is the black market premium (BMP) for foreign exchange. While the BMP is a direct measure of exchange rate misalignment, we follow Rodriguez and Rodrik (2001) who view BMP as a proxy for broader distortions in macroeconomic policy.

Our second policy indicator is the nominal rate of assistance to agricultural importables, a sectoral indicator of trade policy intervention, which we take from the World Bank's database on Distortions to Agricultural Incentives (Anderson 2009). When an ad valorem tariff is the sole policy intervention for good $(x)$, the nominal rate of assistance for commodity $x$ is:

(3) $\quad N R A_{x}=\frac{E * P\left(1+t_{m}\right)-E * P}{E * P}=t_{m}$ where $t_{m}$ is tariff rate, $E$ is the nominal exchange rate, and $P$ is the dollar-denominated world price of the commodity. The nominal rates of assistance for individual crops may be aggregated to form the nominal rate of assistance for agricultural importables (NRA_totm), which are typically foodgrains. Food imports compete with the product of 
Africa's famers for the domestic market and the NRA_totm therefore determines the prices at which local producers can sell what they grow. It also influences the distribution of income, as the lower prices that reduce the incomes of rural producers enhance the purchasing power of urban consumers. It follows from our central line of reasoning that the enfranchisement of the rural majority should be associated with decreased assistance for competing agricultural imports.

The Relative Rate of Assistance (RRA) is calculated as:

$$
R R A=\left[\frac{1+N R \text { Aag }^{t}}{1+N R \text { Anonag }^{t}}-1\right]
$$

where $\mathrm{NRA}_{\mathrm{ag} / \text { nonag }}$ represents an aggregate index of the commodity-specific NRAs for the agricultural and nonagricultural sectors of each country. The RRA provides a measure of the relative level of protection conferred upon agricultural and non-agricultural (manufactured) goods. When agriculture is relatively favored by trade, the RRA is greater than one; when disfavored, it is less. The RRA therefore provides a measure of "urban bias".

Table 4 provides descriptive statistics for these data.

\section{B. Bivariate Relations}

To motivate the analysis that follows, we introduce Figure 3, which distinguishes the time path of TFP growth rates in observations with and without electoral competition ${ }^{15}$.

\footnotetext{
${ }^{15}$ Net of adjustments for input quality.
} 
The TFP growth rate in settings characterized by electoral competition progressively diverges from the TFP growth rate in settings that lacked it. On average, countries with electoral competition experienced agricultural TFP growth of $1.04 \%$ per year, while the average rate was only $0.48 \%$ per year in countries without. ${ }^{16}$

We also introduce Figure 4, which compares government policies in country-years with and without electoral competition. Each panel in Figure 4 contains a box that depicts the portion of the observations of a variable that fall within the interquartile range, i.e. those whose values place them between the lower $25 \%$ and the upper $25 \%$ of the range of the values of the variable. The horizontal lines within the boxes mark the variable's median value. The upper and lower horizontal lines laying outside the boxes mark the upper and lower values of the data.

The data suggest that governments headed by an executive chosen in a competitive election not only spend more on agricultural research, secure higher levels of educational attainment, and pave a larger percentage of their roads. The data also suggest that they exercise greater fiscal and monetary restraint than do their authoritarian counterparts (as indicated by the virtual absence of black markets for their currencies) and intervene in markets in ways less likely to shift relative prices against farmers (as indicated by their relative rates of assistance). Calculating the means, we apply one-sided t-tests to the differences and find each to be significant and in the expected direction. Governments in competitive political systems adopt policies that lower the costs, increase the earnings, and strengthen the incentives for farmers.

\footnotetext{
${ }^{16}$ These averages are statistically different in a two-sided t-test $(\mathrm{P}=0.0014)$.
} 
In the estimates we develop below, we focus in particular on the nominal rate of assistance to agricultural importables. In Figure 5, we superimpose a smoothed version of the mean RRA over the TFP growth profiles. The Figure underscores that TFP growth declined when urban bias was increasing and increased when urban bias was decreasing. The difference in the mean growth rates is statistically different at greater than the .01 level.

To probe deeper and more rigorously, we turn to multivariate analysis.

\section{C. A Deeper Look}

Tables 5-7 provide both the structure of and evidence for our argument. They report the total effect of institutional reform on the growth of total factor productivity in agriculture; the mediated effect, i.e. its impact on policies that themselves affect TFP growth; and the direct effect (McKinnon 2008; Imai, Keele, et. al., 2010). Given that political reform and the growth of total factor productivity in agriculture could be the joint products of variables excluded from the analysis, in each table, we introduce country fixed effects to account (at least) for the time-invariant unobservable characteristics. ${ }^{17}$ And because of

\footnotetext{
${ }^{17}$ Block (2010), among others, found that expenditures on agricultural R\&D explain a substantial share of TFP growth, and our illustrative result in Figure 4 indicates that spending on R\&D is higher in settings with electoral competition. Thus, we must be concerned that excluding $\mathrm{R} \& \mathrm{D}$ expenditures from our specification, which we are forced to do by the lack of a sufficiently large common sample, introduces potential bias into our estimates of the effect of electoral competition on TFP. However, the magnitude of any potential bias is a direct function of the correlation between (excluded) R\&D and (included) electoral competition. The simple correlation between R\&D expenditures and EIEC is low $(0.11)$ and the R-squared in a fixed-effects regression of $(\log ) \mathrm{R} \& \mathrm{D}$ on our electoral competition dummy is essentially zero $(0.0008)$. These considerations suggest that excluding $\mathrm{R} \& \mathrm{D}$ from our specifications does not significantly influence our finding for electoral competition. In addition, virtually all of the variation in R\&D is "between" rather than "within" variation (the between coefficient of variation is nearly 4 times greater than the within), suggesting that country dummies absorb nearly all of the variation in R\&D.
} 
the possibility of reciprocal causality in the relationship between political reform and productivity growth, we also make use of instrumental variables, introducing the level of political competition in neighboring states (lagged by one year) and the end of the Cold War as excluded instruments in a fixed effects two-stage least squares estimator.

Table 5 presents estimates of the total effect of institutional change on the rate of growth of total agricultural productivity in Africa 1961-2007. Columns 1 and 2 address the basic relationship between electoral competition and agricultural TFP growth. Controlling only for a year trend and country fixed effects, we find that electoral competition increases TFP growth by about 0.7 percentage points. Instrumenting -- as described above -- for electoral competition increases this point estimate by approximately one percentage point (column 2). ${ }^{18}$ We introduce additional controls, seeking to take into account the impact of Africa's endemic civil conflicts and the share of its rural population. These controls enter (individually in columns 3 and 4, and together in column 5) with the expected signs and have no impact on our estimated effect of electoral competition on agricultural TFP growth. In column 6 we deepen our analysis by including the interaction between our dummy for electoral competition and the rural population share. We hypothesize that if outcomes favorable to agriculture are more likely when policymakers face electoral competition, then the magnitude of the effect should itself be a positive function of the rural population share. The results in column 5 are therefore suggestive: the point estimates increase with the rural population share. They are not statistically different from one another, however.

\footnotetext{
${ }^{18}$ The Cragg-Donald F-tests of excluded instruments uniformly support the strength of our instruments, and the Sargan-Hansen $\mathrm{J}$ statistic uniformly fails to reject the null hypothesis that the instruments are exogenous.
} 
In Table 6, we explore the impact of institutions on policy choice, which we view as mediating between the introduction of political competition and growth of total factor productivity. We assess the effect of electoral competition on the two policy variables RRA (in columns 1 and 2) and BMP (in columns 3 and 4). In both sets of equations, we allow the effect of electoral competition to vary as a function of the rural population share; and we estimate each model by both fixed effects and fixed effects two-stage least squares using the identification strategy outlined above.

The coefficients in column 1 confirm that the magnitude of the relationship between institutional change and policy choice is a function of the size of the rural electorate: the greater the portion of the total population that lives in rural areas, the greater the reduction in urban bias (e.g., the higher or less negative the RRA) when governments must compete for votes. Column 2 corrects for the potential endogeneity of electoral competition and confirms that more favorable treatment is given farmers by governments that must compete for votes to secure public office. We also find (in columns 3 and 4) that electoral competition reduces the black market premium.

In Table 7, we estimate the direct and indirect impact of institutional change by adding our mediating policy variables, RRA and BMP, to the specification from Table 5. In columns 1 and 3, respectively, we first measure the total impact (for the available sample set of observations) of electoral competition by excluding each policy variable. In columns 2 and 4, we then add the policy variables. The change in the point estimate for 
electoral competition when the policy variable is added provides an estimate of the extent to which electoral competition operates through its impact on the policy variable.

Comparing the point estimates for electoral competition in columns 1 and 2, we find little effect of including RRA. This suggests that while RRA is influenced by electoral competition, most of total effect of electoral competition is direct; it runs through channels other than its impact on relative prices. Columns 3 and 4 suggest that some of the effect of electoral competition on agricultural TFP growth may operate through improved macroeconomic policy. The estimated coefficient on electoral competition is reduced by the inclusion of black market premium, though the difference in the point estimates for electoral competition in columns 3 and 4 is not statistically significant. ${ }^{19}$

Electoral competition thus leads directly to an increase in the growth rate of agricultural TFP growth on the order of one percentage point. We can only speculate on the channels through which it does so. Mechanisms that might be explored include the return of private agents to the rural economy, the reduced regulation of agricultural markets, improved rural infrastructure, and increased rural incomes as a result of greater government spending on roads and public facilities. Electoral competition influences agricultural TFP indirectly as well. Given that the majority of the electorate resides in rural areas, when competing for majorities at the polls, politiciansns now have strong incentives to adopt policies that increase the returns to farming..

\footnotetext{
${ }^{19}$ Here, too, we instrument for the existence of electoral competition. Diagnostic tests support the strength of our instruments, though the tests of overidentifying restrictions in columns 3 and 4 suggest some concern for their exogeneity. Given the weakness of this test, and that previous tests of similar models gave rise to no concerns, we report this finding, but do not consider it a threat to our argument.
} 
Page 22

\section{Conclusion}

The late century changes in Africa's political institutions constituted a natural experiment, enabling scholars to test institutionalist arguments. In this article, we have sought to take advantage of the data thus supplied.

In Africa, we find, institutions bear a systematic and significant relationship to economic performance. At the micro-level, political reform is (Granger) causally related to economic growth; and at the micro-level, positively and significantly related to TFP growth in agriculture. The latter relationship is both direct and through its impact on government policies. Given that Africa's electorate is largely rural, the movement to majoritarian institutions led to the creation of an electorate dominated by farmers, thus weakening the governments' commitment to policies favoring consumers at the expense of the producers of agricultural products.

Our analysis of Africa's "great experiment" thus suggests that the hopes of the late century reformers were fulfilled: changes in institutions led to changes in policy and to economic growth. They also suggest that the new instituionalism is right: the rules that structure the use of power influence the performance of economies. 


\section{References}

Bates, R. H., P. Brock, et al. (1991). "Risk and Trade Regimes: Another Exploration." International Organization 45(1): 1-18.

Bates, R. H. and S. Block (2010). Revisiting African Agriculture: Institutional Change and Productivity Growth. Cambridge MA, Weatherhead Center.

Bates, R. H. and S. A. Block (2011). Revisiting African Agriculture: institutional Change and Productivity Growth. Working Paper. Cambridge MA, Weatherhead Center.

Bates, R. H., K. Ferree, et al. (1996). Toward the Systematic Study of Transitions. Development Discussion Paper No. 256. Cambridge MA, Harvard Institute for International Development.

Bates, R. H., A. Greif, et al. (2002). "Organizing Violence." Journal of Conflict Resolution(October).

Beck, T., G. Clarke, et al. (2001). "New Tools and New Tests in Comparative Political Economy: The Database of Political Institutions." World Bank Economic Review.

Becker, G. (1983). "A Theory of Competitition among Pressure Groups for Political Influence." The Quarterly Journal of Economics 98: 371-400.

Besley, T. and M. Kudamatsu (2006). "Health and Democracy." American Economic Review 96(2): 313-318.

Block, S. (2010). The Decline and Rise of Agricultural Productivity in Sub-Saharan Africa Since 1961. Cambridge MA, National Bureau f Economic Research, Africa Project.

Buchanan, J. and G. Tullock (1962). The Calculus of Consent. Ann Arbor, MI, University of Michigan Press.

Buchanan, J. M. (1989). Essays on the Political Economy. Honolulu, University of Hawaii Press.

Fayad, G., B. R.H., et al. (2011). Income and Democracy: Lipset's Law Inverted. OxCarre Research Paper 61. Oxford, Oxford Center for the Analysis of Research Rich Economies.

Ferree, K. and S. Singh (1999). Institutional Change and Economic Performance in Africa, 1970-1995. Annual Meetings of the American Political Science Association, Atlanta.

Fosu, A. K. (2008). "Democracy and Growth: Implications of Increasing Electoral Competiveness." Economic Letters 100(September): 442-444.

Freedom House (2011). Freedom in the World.

Glaeser, E., R. La Porta, et al. (2004). "Do Institutions Cause Growth?" Joural of Economic Growth 9: 271-304.

Grundlach, E. and M. Paldam (2008). Income and Democracy: A Comment on Acemoglu, Johnson, Robinson and Yared. Kiel Working Paper No. 1521. University of Kiel.

Hirshleifer, J. (1994). "The Dark Side of the Force." Economic Inquiry 32(1-10).

Imai, K., L. Keele, et al. (2010). Unpacking the Black Box: Learning about Causal Mechanisms From Experimental Observational Studies. Working Paper. Princeton, Department of Government. 
Krueger, A. O., M. Schiff, et al., Eds. (1992). The Political Economy of Agricultural Pricing Policies, 5 vols. Baltimore, Published for the World Bank by Johns Hopkins University Press.

Ndulu, B. J., S. A. O'Connell, et al. (2008). The Political Economy of Economic Growth in Africa, 1960-2000. New York, Cambridge University Press.

Nkurunziza, J. D. and R. H. Bates (2003). Political Institutions and Economic Growth in Africa. CID Working Paper No. 98. Cambridge MA, Center for International Development, Harvard University.

North, D. C. (1981). Structure and Change in Economic History. New York, Norton.

North, D. C. (1990). Institutions, Institutional Change, and Economic Performance. New York, Cambridge University Press.

North, D. C. and R. P. Thomas (1973). The Rise of the Western World. Cambridge, Cambridge University Press.

Olson, M. (1985). "Space, Agriculture, and Organization." Journal of Agricultural Economics 67(5): 928-937.

Pesaran, M. H. (1997). "The Role of Economic Modeling in he Long Run." The Economic Journal 107(178-191).

Pesaran, M. H. and R. Smith (1995). "Estimating Long-run Relationships from Dynamic Heterogeneous Panels." Journal of Econometrics 68(1): 79-113.

Posner, D. and D. Young (2007). "The Institutionalization of Political Power in Africa." Journal of Democracy 18(3): 126-140.

Powell, J. M. and C. L. Thyne (2011). Global instances of coups from 1950 to 2010: A new dataset. Journal of Peace Research 48(2): 249-259.

Radelet, S. (2010). Emerging Africa: How 17 Countries Are Leading the Way. Washington DC, Center for Global Development.

Rodrik, D. and F. Rodriguez (1999). Trade Policy and Economic Growth: A Skeptic's Guide to the Cross-National Evidence. Center for Economic Policy, Discussion Paper No. 2143.

Rodrik, D., A. Subramanian, et al. (2002). Institutions Rule: The Primacy of Institutions over Geography and Integration in Economic Development. NBER Discussion Paper 9305. Cambridge MA, NBER.

Stasavage, D. (2005). "Democracy and Education Spending in Africa." American Political Science Review 49(2): 343-358.

World Bank, (1991). Governance and Development. Washington DC, The World Bank. World Bank, (1991). World Development Report. Washington DC, The World Bank. 
Page 25

Figure 1.A. Political institutions

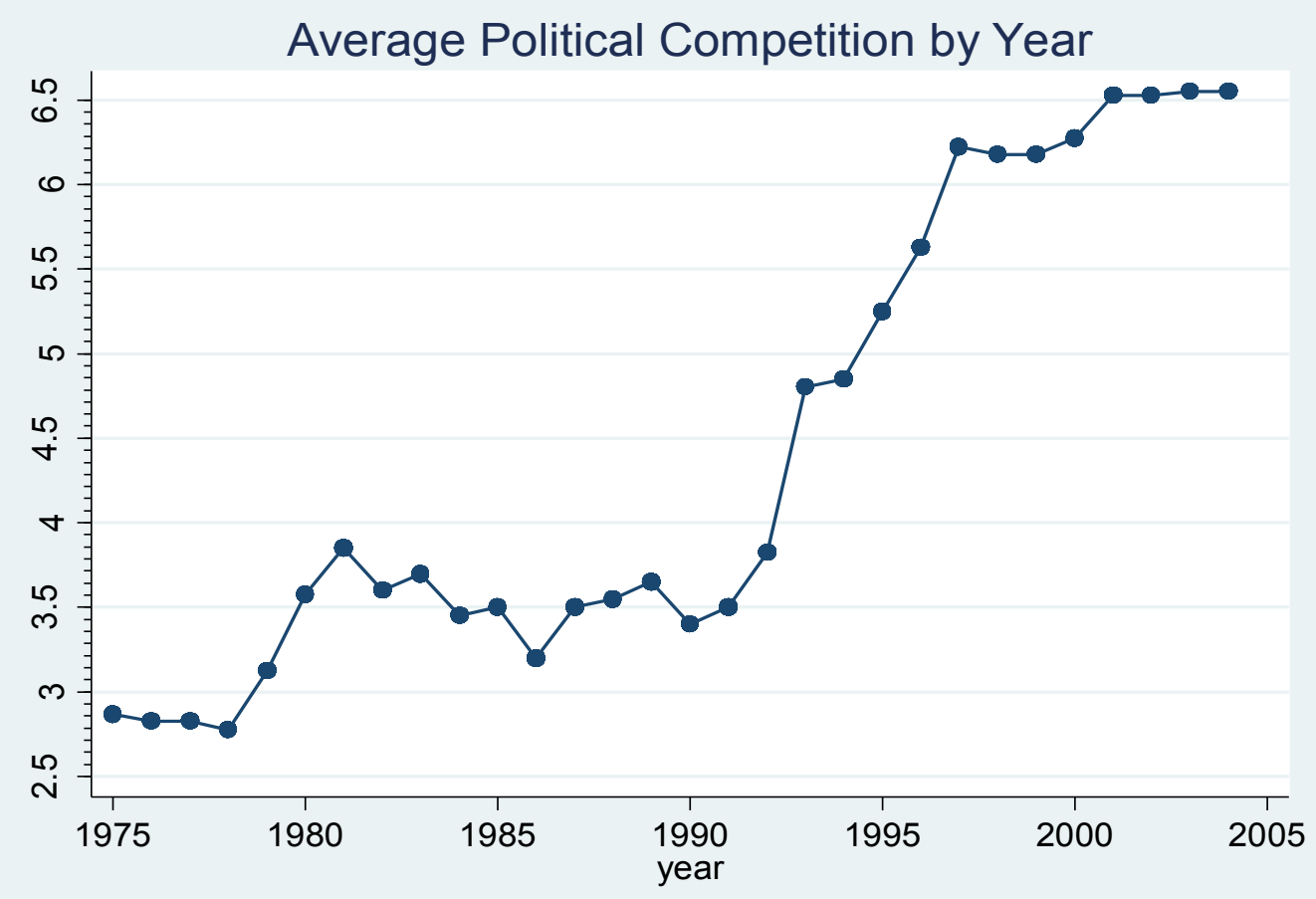

Figure 1. B Party Systems

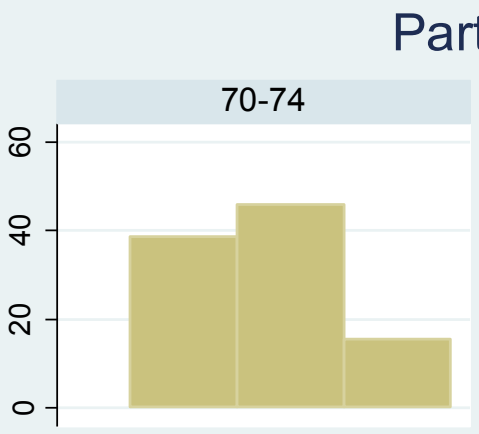

85-89

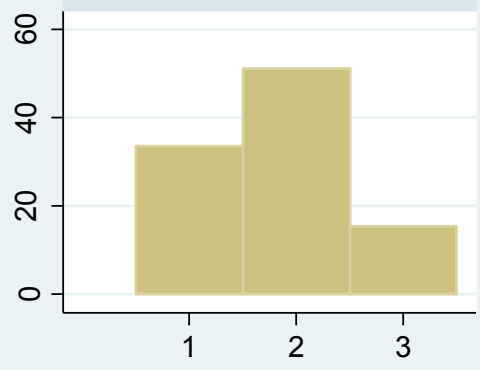

1 = No Party System 2 = Single Party System 3 = Competitive Party System
80-84
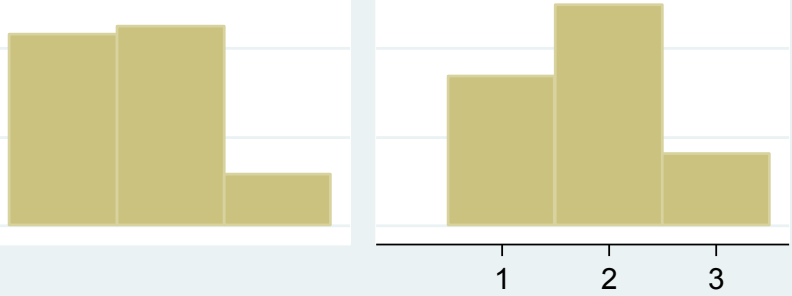

90-95

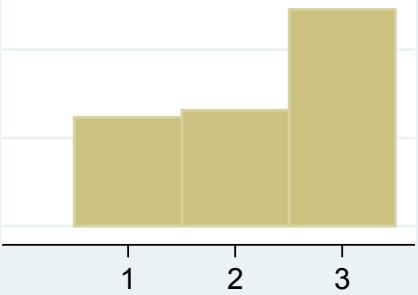


Page 26

Figure 2. Agricultural TFP Growth Rates Adjusted for Input Quality

\section{Agricultural TFP Growth Rates, SSA Crops}

semi-parametric regressions adjusting for input quality

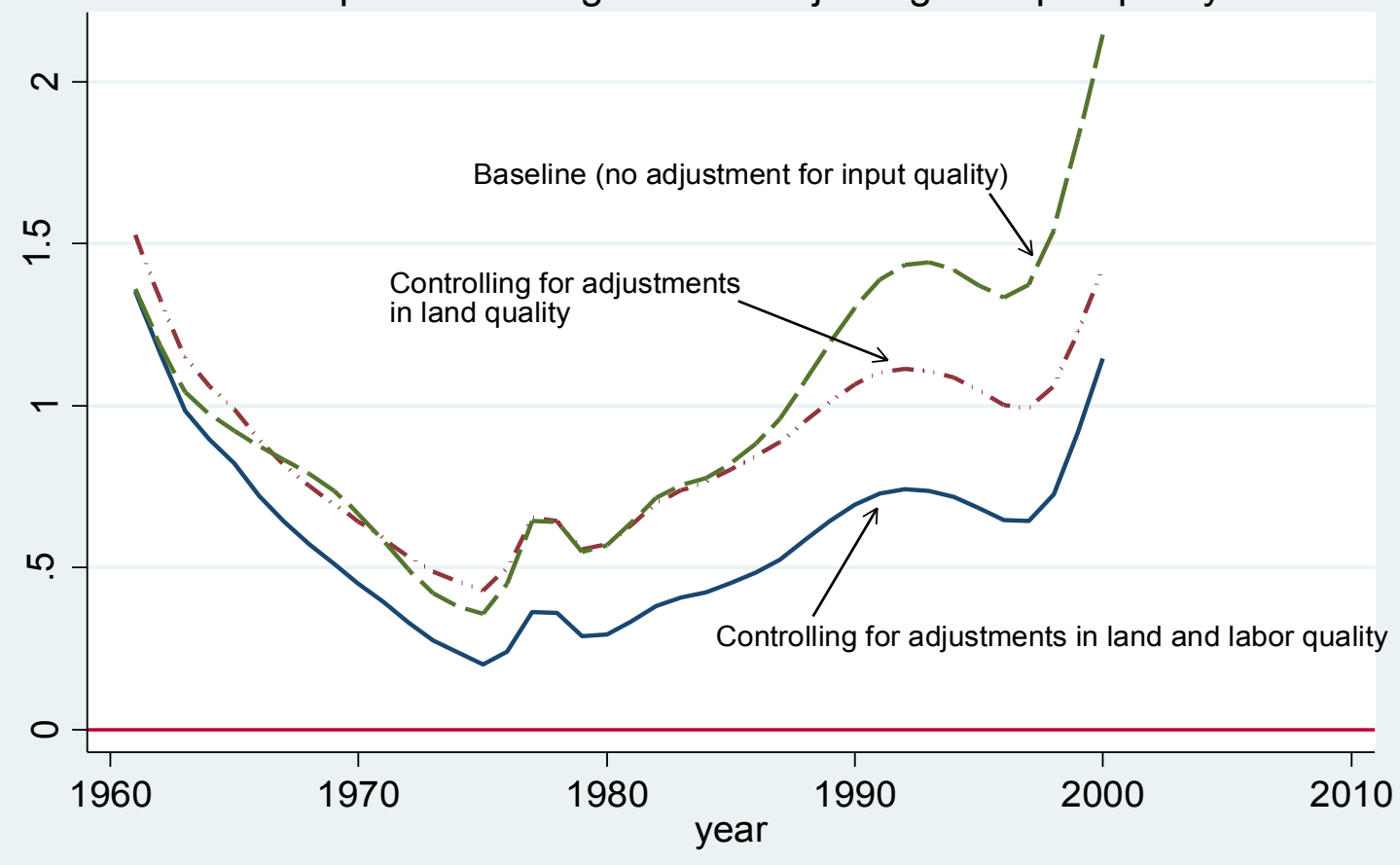


Page 27

Figure 3. Agricultural TFP Growth Profile for Country-Years With and Without Electoral Competition

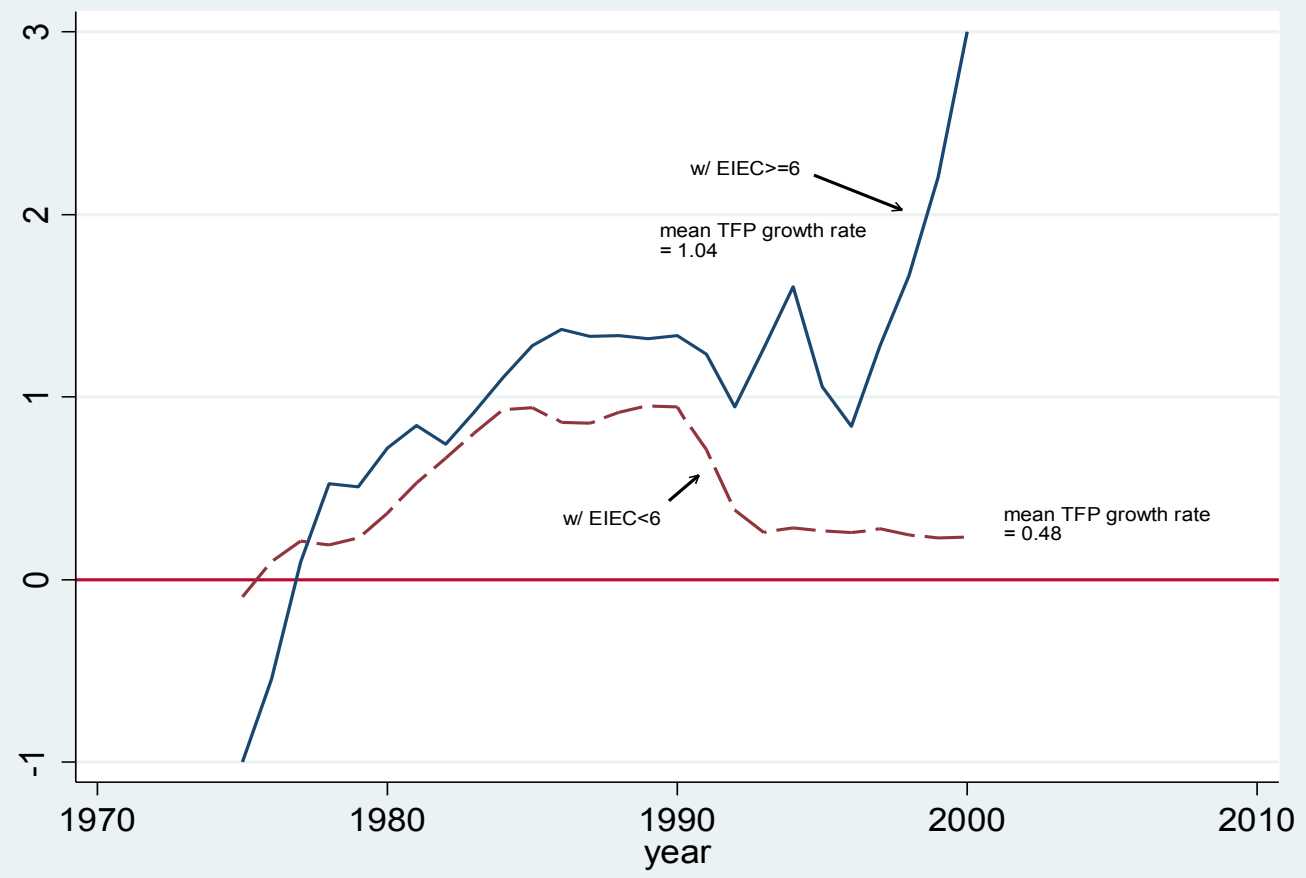


Page 28

Figure 4: Policy Differences: With and Without Electoral Competition

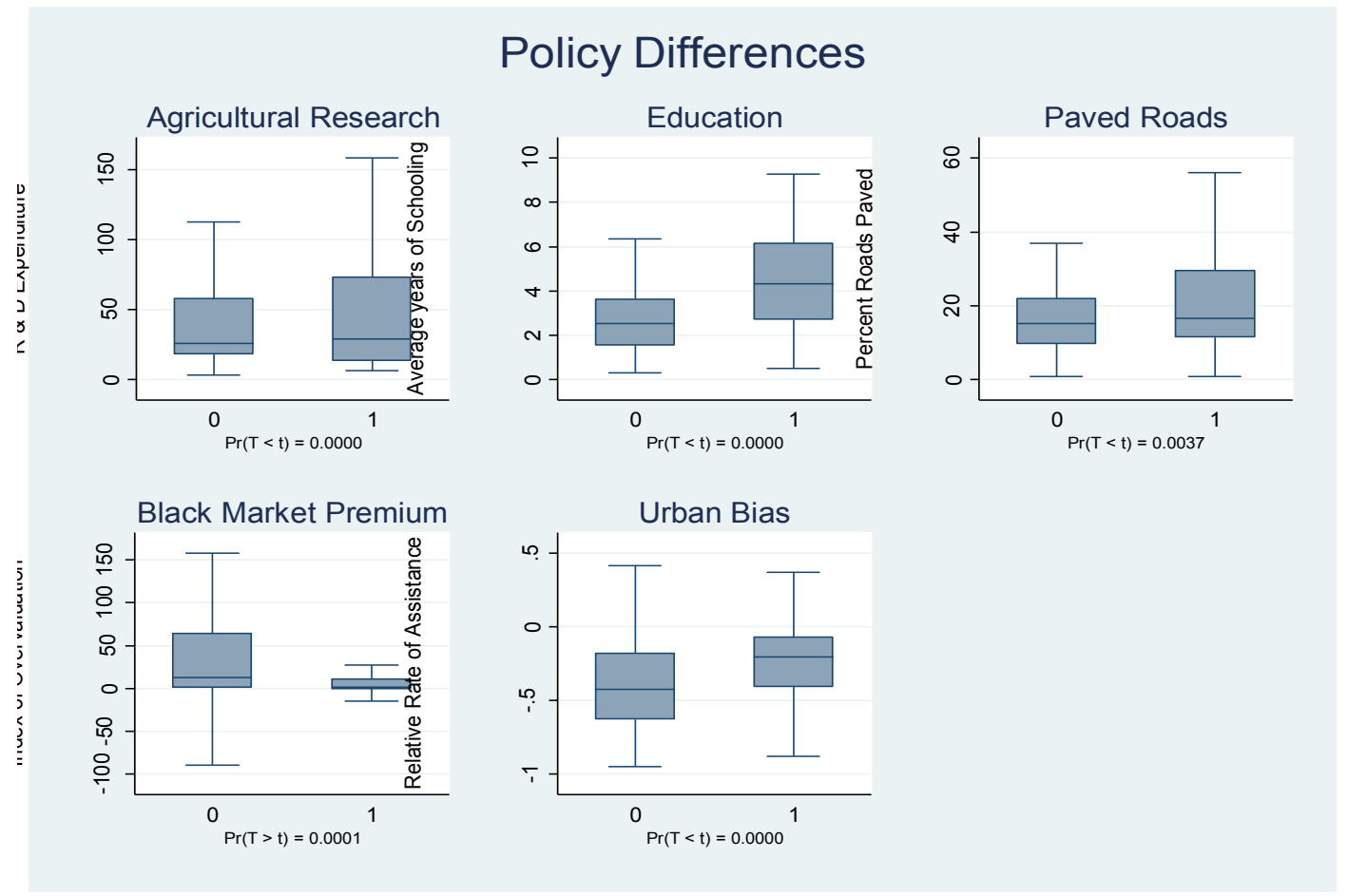


Page 29

Figure 5. Effect of Nominal Rate of Assistance to Agricultural Importables on Agricultural TFP Growth

\section{Agricultural TFP Growth \& Relative Rate of Assistance}

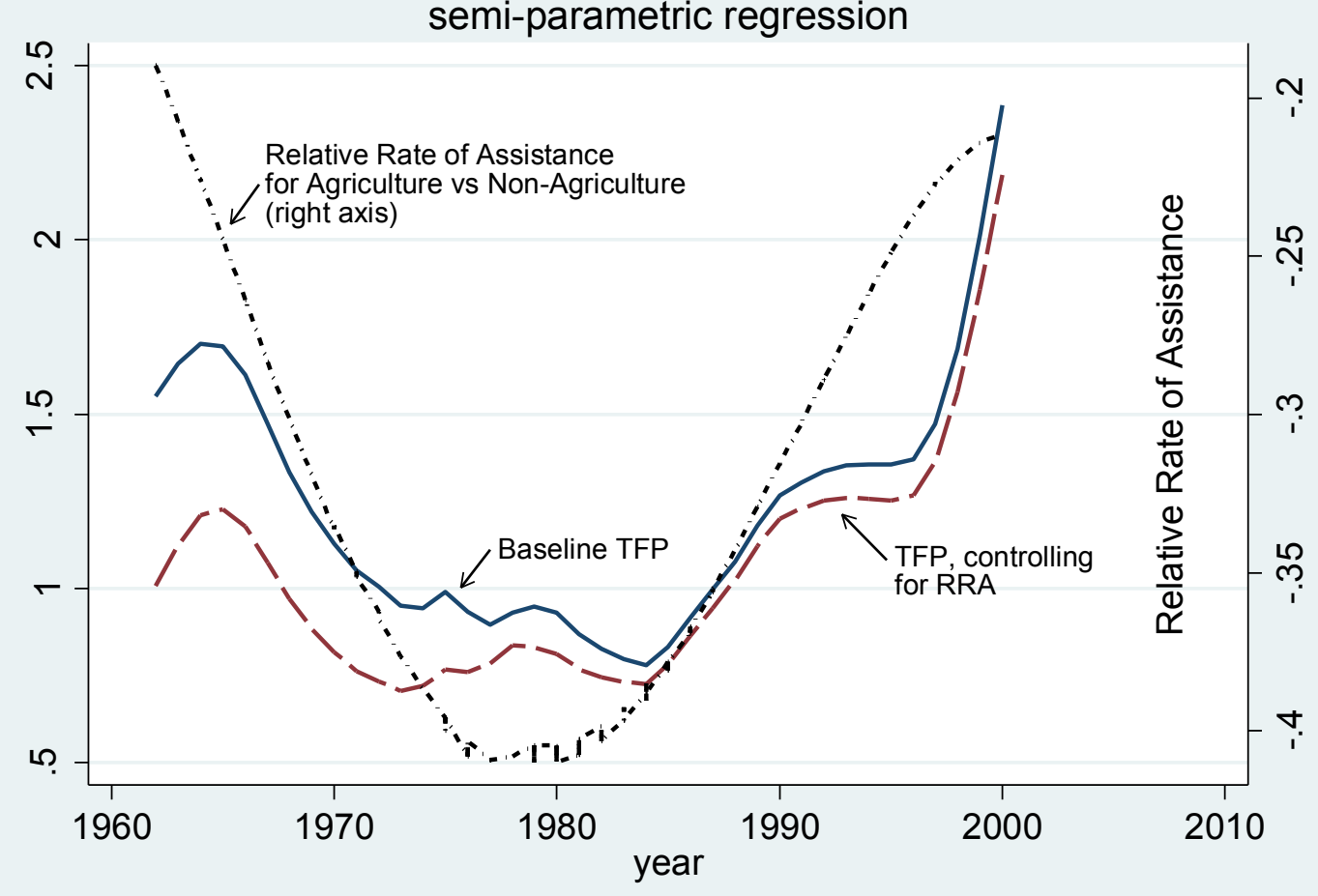


Page 30

Table 1: Augmented PMG estimation; Overall sample (N=105); 1955-2007

Dependent variable: Polity IV Measure of Democracy

\begin{tabular}{l|ccc}
\hline Long-run Coefficients & PMG & MG & Hausman Test \\
& 1 & 2 & 3 \\
\hline Log Income per Capita & $-1.239^{* * *}$ & 0.390 & 1.44 \\
& $(0.153)$ & $(1.368)$ & {$[0.23]$} \\
World Democracy & & & \\
& $0.800^{* * *}$ & $0.926 * * *$ & 0.80 \\
World Output & $(0.029)$ & $(0.143)$ & {$[0.37]$} \\
& $3.059 * * *$ & 0.293 & 0.90 \\
& $(0.547)$ & $(2.958)$ & {$[0.34]$} \\
& & & 2.39 \\
& Joint Hausman test & {$[0.50]$} \\
\hline Error Correction Coefficient & $-0.264 * * *$ & $-0.469 * * *$ & $(0.034)$ \\
\hline
\end{tabular}

Notes: All equations include a constant country-specific term. Numbers reported in parentheses are standard errors. Numbers reported in brackets are p-values.***, **, and * indicate significance respectively at the 1,5 , and 10 percent levels. We use the Schwartz Bayesian optimal lag selection Criterion subject to a maximum lag of three. World democracy and world output are respectively the cross-sectional averages of democracy and output, which we take as proxies of the common unobserved global shocks. 
Table 2: Granger causality tests

\begin{tabular}{|c|c|c|c|c|}
\hline \multirow[b]{2}{*}{ Null hypothesis } & \multicolumn{4}{|c|}{ Overall sample } \\
\hline & Observations & Lags & F-stat & Probability \\
\hline Democracy does not & 4532 & & & \\
\hline Granger cause income & & 3 & 5.472 & 0.001 \\
\hline \multirow[t]{2}{*}{$\begin{array}{l}\text { Income does not Granger } \\
\text { cause democracy }\end{array}$} & 4532 & 3 & 6.870 & 0.000 \\
\hline & \multicolumn{4}{|c|}{ Sub-Saharan Africa sample } \\
\hline Null hypothesis & $\begin{array}{c}\text { Observation } \\
\mathrm{s}\end{array}$ & Lags & F-stat & Probability \\
\hline $\begin{array}{l}\text { Democracy does not } \\
\text { Granger cause income }\end{array}$ & 1741 & 3 & 2.574 & 0.052 \\
\hline \multirow[t]{2}{*}{$\begin{array}{l}\text { Income does not Granger } \\
\text { cause democracy }\end{array}$} & 1741 & 3 & 1.521 & 0.207 \\
\hline & \multicolumn{4}{|c|}{ Non-Sub-Saharan Africa sample } \\
\hline Null hypothesis & $\begin{array}{c}\text { Observation } \\
\mathrm{s}\end{array}$ & Lags & F-stat & Probability \\
\hline $\begin{array}{l}\text { Democracy does not } \\
\text { Granger cause income }\end{array}$ & 2791 & 3 & 2.612 & 0.050 \\
\hline $\begin{array}{l}\text { Income does not Granger } \\
\text { cause democracy }\end{array}$ & 2791 & 3 & 5.283 & 0.001 \\
\hline
\end{tabular}

Note: In testing whether democracy Granger causes income, income is regressed on lags of income and democracy, and the reported F-stat is a Wald-type test of the joint significance of all estimated coefficients on such lags. We also report the probability of rejecting the null hypothesis. 
Page 32

Table 3: Augmented PMG estimation; Sub-Saharan Africa sample ( $N=42)$; 1955-2007

Dependent variable: Log of GDP per capita

\begin{tabular}{l|ccc}
\hline Long-run Coefficients & PMG & MG & Hausman Test \\
\hline Democracy & $0.015^{* * *}$ & 0.081 & 1.46 \\
& $(0.002)$ & $(0.055)$ & {$[0.23]$} \\
World Democracy & & & \\
& $0.018^{* * *}$ & -0.018 & 2.13 \\
& $(0.003)$ & $(0.025)$ & {$[0.14]$} \\
World Output & $1.176^{* * *}$ & $1.191 * * *$ & 0.00 \\
& $(0.103)$ & $(0.363)$ & {$[0.97]$} \\
& & & 2.64 \\
& Joint Hausman test & {$[0.45]$} \\
\hline Error Correction Coefficient & $-0.122^{* * *}$ & $-0.259 * * *$ & \\
& $(0.030)$ & $(0.034)$ & \\
\hline
\end{tabular}

Notes: All equations include a constant country-specific term. Numbers reported in parentheses are standard errors. Numbers reported in brackets are p-values.***,**, and * indicate significance respectively at the 1, 5, and 10 percent levels. We use the Schwartz Bayesian optimal lag selection Criterion subject to a maximum lag of three. World democracy and world output are respectively the cross-sectional averages of democracy and output, which we take as proxies of the common unobserved global shocks 
Page 33

Table 4. Variables and Descriptive Statistics

\begin{tabular}{|c|c|c|c|c|c|c|}
\hline Variable & $\underline{\mathrm{Obs}}$ & $\underline{\text { Mean }}$ & $\underline{\text { Std. Dev. }}$ & $\underline{\text { Min }}$ & $\underline{\text { Max }}$ & Source: \\
\hline Agricultural TFP Growth & 1494 & 0.614 & 2.117 & -7.694 & 8.247 & Block (2010) \\
\hline $\begin{array}{l}\text { Dummy }=1 \text { if Exec. Index of } \\
\text { Electoral Competition }>6\end{array}$ & 1460 & 0.427 & 0.495 & 0.000 & 1.000 & Beck and Clarke (2009) \\
\hline $\begin{array}{l}\text { Neighbors' Executive Index of } \\
\text { Electoral Competition }\end{array}$ & 1230 & 4.289 & 1.586 & 1.500 & 7.000 & Based on Beck \& Clarke (2009 \\
\hline $\begin{array}{l}\text { Relative Rate of Assistance (RRA) } \\
\text { Black Market Premium on Foreign }\end{array}$ & 642 & -0.279 & 0.299 & -0.946 & 1.295 & Anderson and Valenzuela (200 \\
\hline Exchange & 1321 & 1.361 & 3.436 & -6.908 & 6.122 & World Devt Indicators (2009) \\
\hline Civil War dummy & 2162 & 0.166 & 0.372 & 0.000 & 1.000 & Sambanis and Doyle (2006) \\
\hline Rural Population Share & 2064 & 71.713 & 16.410 & 12.700 & 97.960 & World Devt Indicators (2009) \\
\hline
\end{tabular}

Countries for which we have estimates of agricultural TFP growth (boldface indicates the existence of data for RRA for that country): Angola, Benin, Botswana, Burkina Faso, Burundi, Cameroon, Central African Republic, Democratic Republic of Congo, Côte d'Ivoire, Equatorial Guinea, Gabon, Gambia, Ghana, Guinea, Guinea-Bissau, Kenya, Malawi, Mali, Mauritania, Mauritius, Mozambique, Niger, Nigeria, Rwanda, Senegal, Seychelles, Sierra Leone, Somalia, South Africa, Swaziland, Tanzania, Togo, Uganda, Zimbabwe. 
Table 5. Effect of Electoral Competition on Agricultural TFP Growth for Crop Agriculture in SSA

\begin{tabular}{|c|c|c|c|c|c|c|}
\hline VARIABLES & $\begin{array}{l}(1) \\
\text { FE }\end{array}$ & $\begin{array}{c}(2) \\
\text { FE-2SLS }\end{array}$ & $\begin{array}{c}(3) \\
\text { FE-2SLS }\end{array}$ & $\begin{array}{c}(4) \\
\text { FE-2SLS }\end{array}$ & $\begin{array}{c}(5) \\
\text { FE-2SLS } \\
\end{array}$ & $\begin{array}{c}(6) \\
\text { FE-2SLS } \\
\end{array}$ \\
\hline Electoral Comp dummy & $\begin{array}{l}0.691^{*} \\
(0.376)\end{array}$ & $\begin{array}{c}1.670 * * * \\
(0.385)\end{array}$ & $\begin{array}{c}1.633 * * * \\
(0.380)\end{array}$ & $\begin{array}{c}1.945 * * * \\
(0.355)\end{array}$ & $\begin{array}{l}1.928 * * * \\
(0.353)\end{array}$ & $\begin{array}{c}1.414 \\
(0.969)\end{array}$ \\
\hline Year trend & $\begin{array}{r}0.0249 \\
(0.0335)\end{array}$ & $\begin{array}{r}-0.00780 \\
(0.0145)\end{array}$ & $\begin{array}{r}-0.00453 \\
(0.0142)\end{array}$ & $\begin{array}{c}- \\
0.109 * * * \\
(0.017)\end{array}$ & $\begin{array}{c}- \\
0.106 * * * \\
(0.0167)\end{array}$ & $\begin{array}{c}- \\
0.111^{* * *} \\
(0.0193)\end{array}$ \\
\hline Civil War Dummy & & & $\begin{array}{c}- \\
0.440^{* * *} \\
(0.157)\end{array}$ & & $\begin{array}{l}-0.179 \\
(0.145)\end{array}$ & $\begin{array}{l}-0.174 \\
(0.147)\end{array}$ \\
\hline Rural Pop Shr & & & & $\begin{array}{c}- \\
0.168 * * * \\
(0.014)\end{array}$ & $\begin{array}{c}-165^{* * *} \\
(0.0139)\end{array}$ & $\begin{array}{c}- \\
0.175^{* * *} \\
(0.0232)\end{array}$ \\
\hline EleComp x Rural Pop Shr & & & & & & $\begin{array}{l}0.00799 \\
(0.0146)\end{array}$ \\
\hline Constant & $\begin{array}{l}-49.54 \\
(66.47)\end{array}$ & & & & & \\
\hline Observations & 635 & 635 & 635 & 635 & 635 & 635 \\
\hline R-squared & 0.116 & 0.049 & 0.066 & 0.211 & 0.215 & 0.206 \\
\hline Number of countries & 27 & 27 & 27 & 27 & 27 & 27 \\
\hline $\begin{array}{l}\text { Sargan-Hansen (P-value) } \\
\text { Cragg-Donald Wald (F-stat) }\end{array}$ & & $\begin{array}{l}0.482 \\
53.29^{\mathrm{a}}\end{array}$ & $\begin{array}{c}0.70 \\
53.80^{\mathrm{a}}\end{array}$ & $\begin{array}{l}0.418 \\
52.00^{\mathrm{a}}\end{array}$ & $\begin{array}{l}0.502 \\
52.38^{\mathrm{a}}\end{array}$ & $\begin{array}{l}0.510 \\
29.94^{\mathrm{a}}\end{array}$ \\
\hline \multicolumn{7}{|l|}{$\begin{array}{l}\text { Partial Effect of Elecomp } \\
\text { with rural pop share }=\end{array}$} \\
\hline $63 \%\left(25^{\text {th }}\right.$ pctl $)$ & & & & & & $\begin{array}{l}1.90^{* * *} \\
(0.356)\end{array}$ \\
\hline $72 \%\left(50^{\text {th }}\right.$ pctl $)$ & & & & & & $\begin{array}{l}1.98 * * * \\
(0.376)\end{array}$ \\
\hline $85 \%\left(75^{\text {th }}\right.$ pctl $)$ & & & & & & $\begin{array}{c}2.08 * * * \\
(0.475)\end{array}$ \\
\hline
\end{tabular}

Robust standard errors in parentheses. $* * * \mathrm{p}<0.01, * * \mathrm{p}<0.05, * \mathrm{p}<0.1$ Excluded instruments used in $1^{\text {st }}$ stage regressions: lagged mean level of electoral competition in neighboring countries, dummy for Cold War (and interaction of rural population share with Cold War dummy in column 6, only). ${ }^{a}$ Exceeds 10\% maximal IV size value for Stock-Yogo weak ID test. 
Page 35

Table 6. Effect of Electoral Competition on RRA and Black Market Premium

\begin{tabular}{|c|c|c|c|c|}
\hline VARIABLES & $\begin{array}{l}(1) \\
\text { FE }\end{array}$ & $\begin{array}{c}(2) \\
\text { FE-2SLS }\end{array}$ & $\begin{array}{l}(3) \\
\text { FE }\end{array}$ & $\begin{array}{c}(4) \\
\text { FE-2SLS }\end{array}$ \\
\hline Dep Var: & \multicolumn{2}{|c|}{ RRA } & \multicolumn{2}{|c|}{ Black Market Premium (log) } \\
\hline $\begin{array}{l}\text { Electoral Competition } \\
\text { dummy }\end{array}$ & $\begin{array}{l}-0.355 \\
(0.245)\end{array}$ & $\begin{array}{l}-1.067 * * * \\
(0.251)\end{array}$ & $\begin{array}{l}-2.089 \\
(1.977)\end{array}$ & $\begin{array}{l}-8.303 * * * \\
(2.568)\end{array}$ \\
\hline Rural Pop. Share & $\begin{array}{l}-0.0130 \\
(0.00773)\end{array}$ & $\begin{array}{l}-0.0188 * * * \\
(0.00419)\end{array}$ & $\begin{array}{c}0.278 * * * \\
(0.0588)\end{array}$ & $\begin{array}{l}0.143 * * * \\
(0.0397)\end{array}$ \\
\hline $\begin{array}{l}\text { EleComp dummy } x \text { Rural } \\
\text { Pop. Share }\end{array}$ & $\begin{array}{l}0.00685^{*} \\
(0.00340)\end{array}$ & $\begin{array}{l}0.0169 * * * \\
(0.00330)\end{array}$ & $\begin{array}{l}-0.0135 \\
(0.0261)\end{array}$ & $\begin{array}{c}0.0307 \\
(0.0337)\end{array}$ \\
\hline Civil War dummy & $\begin{array}{l}-0.0237 \\
(0.0571)\end{array}$ & $\begin{array}{l}-0.0174 \\
(0.0277)\end{array}$ & $\begin{array}{l}1.239 * * \\
(0.571)\end{array}$ & $\begin{array}{c}1.524 * * * \\
(0.335)\end{array}$ \\
\hline Constant & $\begin{array}{c}0.569 \\
(0.559)\end{array}$ & $\begin{array}{l}1.116^{* * *} \\
(0.373)\end{array}$ & $\begin{array}{c}-17.85^{* * *} \\
(4.349)\end{array}$ & $\begin{array}{c}-11.69 * * * \\
(2.251)\end{array}$ \\
\hline Observations & 399 & 399 & 762 & 762 \\
\hline R-squared & 0.205 & 0.635 & 0.418 & 0.462 \\
\hline Number of countries & 14 & 14 & 38 & 38 \\
\hline F-test of excluded & & 43.26 & & 102.6 \\
\hline instruments & & $47.36^{\mathrm{a}}$ & & $110.3^{\mathrm{a}}$ \\
\hline Sargan Statistic (P-value) & & $0.034 * *$ & & $0.010 * *$ \\
\hline \multicolumn{3}{|l|}{$\begin{array}{l}\text { Partial Effect of EIEC with } \\
\text { rural pop share = }\end{array}$} & $\begin{array}{c}-2.93 * * * \\
(0.552)\end{array}$ & $\begin{array}{c}-6.38 * * * \\
(0.662)\end{array}$ \\
\hline $72 \%\left(50^{\text {th }}\right.$ pctl $)$ & $\begin{array}{l}0.138^{* *} \\
(0.047)\end{array}$ & $\begin{array}{c}0.213 * * * \\
(0.070)\end{array}$ & $\begin{array}{c}-3.059^{* * *} \\
(0.473)\end{array}$ & $\begin{array}{c}-6.09 * * * \\
(0.524)\end{array}$ \\
\hline $85 \%\left(75^{\text {th }}\right.$ pctl $)$ & $\begin{array}{c}0.223 * * * \\
(0.066)\end{array}$ & $\begin{array}{c}0.437 * * * \\
(0.135) \\
\end{array}$ & $\begin{array}{c}-3.226 * * * \\
(0.552) \\
\end{array}$ & $\begin{array}{c}-5.71 * * * \\
(0.610) \\
\end{array}$ \\
\hline $\begin{array}{l}\text { Robust standard errors in par } \\
\text { Excluded instruments for ele } \\
\text { competition in each country' } \\
\text { the Cold War. } \\
\text { a F-test for } 1^{\text {st }} \text {-stage regressio } \\
\text { included interaction of rural }\end{array}$ & $\begin{array}{l}\text { ntheses } \\
\text { oral comp } \\
\text { neighbors, } \\
\text { to predict }\end{array}$ & $\begin{array}{l}<0.01, * * \mathrm{p} \\
\text { n: first lag } \\
\text { dummy var } \\
\text { nteraction te }\end{array}$ & $\begin{array}{l}05, * \mathrm{p}<0.1 \\
\text { he average } 1 \\
\text { e equal to } 1 \\
\text { (excluded in }\end{array}$ & $\begin{array}{l}\text { of electoral } \\
\text { years during } \\
\text { Iments }\end{array}$ \\
\hline
\end{tabular}


Table 7. Effect of Electoral Competition on Agricultural TFP Growth for Crop Agriculture in SSA

\begin{tabular}{|c|c|c|c|c|}
\hline VARIABLES & $\begin{array}{c}(1) \\
\text { FE-2SLS }\end{array}$ & $\begin{array}{c}(2) \\
\text { FE-2SLS }\end{array}$ & $\begin{array}{c}(3) \\
\text { FE-2SLS }\end{array}$ & $\begin{array}{c}(4) \\
\text { FE-2SLS }\end{array}$ \\
\hline Electoral Comp dummy & $\begin{array}{c}1.150 * * \\
(0.485)\end{array}$ & $\begin{array}{c}0.997 * * \\
(0.474)\end{array}$ & $\begin{array}{c}1.285^{* * *} * \\
(0.340)\end{array}$ & $\begin{array}{c}1.039 * * * \\
(0.345)\end{array}$ \\
\hline Relative Rate of Assistance & & $\begin{array}{c}1.747 * * * \\
(0.417)\end{array}$ & & \\
\hline Log Black Mkt Premium & & & & $\begin{array}{c}-0.144 * * * \\
(0.0387)\end{array}$ \\
\hline Rural Pop Shr & $\begin{array}{c}-0.087 * * * \\
(0.0335)\end{array}$ & $\begin{array}{c}-0.0569^{*} \\
(0.0333)\end{array}$ & $\begin{array}{c}-0.195 * * * \\
(0.0152)\end{array}$ & $\begin{array}{c}-0.195 * * * \\
(0.0148)\end{array}$ \\
\hline Year Trend & $\begin{array}{c}-0.051 * * \\
(0.0246)\end{array}$ & $\begin{array}{c}-0.0573 * * \\
(0.0239)\end{array}$ & $\begin{array}{c}-0.101 * * * \\
(0.0157)\end{array}$ & $\begin{array}{c}-0.107 * * * \\
(0.0152)\end{array}$ \\
\hline Civil War Dummy & $\begin{array}{c}-0.0400 \\
(0.218)\end{array}$ & $\begin{array}{c}-0.0432 \\
(0.211)\end{array}$ & $\begin{array}{c}-0.141 \\
(0.153)\end{array}$ & $\begin{array}{c}0.0145 \\
(0.155)\end{array}$ \\
\hline Observations & 268 & 268 & 472 & 472 \\
\hline R-squared & 0.174 & 0.223 & 0.297 & 0.337 \\
\hline Number of Countries & 11 & 11 & 26 & 26 \\
\hline Sargan-Hansen (P-value) & .889 & $0.074 *$ & $0.01 * * *$ & $0.01 * * *$ \\
\hline Cragg-Donald Wald (F-stat) & $28.25^{\mathrm{a}}$ & $27.76^{\mathrm{a}}$ & $48.99^{\mathrm{a}}$ & $44.85^{\mathrm{a}}$ \\
\hline
\end{tabular}

Robust standard errors in parentheses. $* * * \mathrm{p}<0.01,{ }^{* *} \mathrm{p}<0.05,{ }^{*} \mathrm{p}<0.1$ Excluded instruments used in $1^{\text {st }}$ stage regressions: lagged mean level of electoral competition in neighboring countries, dummy for Cold War. ${ }^{a}$ Exceeds $10 \%$ maximal IV size value for Stock-Yogo weak ID test. 